\title{
Column experiments to study the interaction between acid mine drainage and rock and Portland cement
}

\author{
Jordi Cama ${ }^{1, *}$, Joan Gutiérrez-León ${ }^{1}$, Jordi Palau $^{1}$, Lidia Fernández-Rojo ${ }^{1}$, and Josep M. \\ Soler ${ }^{1}$ \\ ${ }^{1}$ Institute of Environmental Assessment and Water Research (IDAEA), CSIC, Barcelona 08034, \\ Catalonia, Spain
}

\begin{abstract}
Interaction between Portland cement, rock (siliceous limestone) and acid mine drainage (AMD) from the Iberian Pyrite Belt (IPB) was studied by means of column experiments at laboratory scale. Synthetic acidic solutions $(\mathrm{pH}=2)$ containing sulfate, $\mathrm{Fe}(\mathrm{II}), \mathrm{Al}, \mathrm{Mg}$ and minor elements such as divalent cations $(\mathrm{Cd}, \mathrm{Zn}, \mathrm{Cu}, \mathrm{Ni}$ and $\mathrm{Cd})$ and an anion As $(\mathrm{V})$ were injected. The interaction was dominated by the dissolution of calcite (main rock phase) and portlandite (one of the main phases of cement). Dissolution of these phases increased the $\mathrm{pH}$ up to $\approx 12$ as portlandite dissolved and up to $\approx 6$ when calcite dissolved. This change in $\mathrm{pH}$ resulted in (1) the precipitation of gypsum, aragonite, schwertmannite, brucite and $\mathrm{Fe}$ - and $\mathrm{Al}$-amorphous phases and (2) the precipitation of $\mathrm{Cd}$, $\mathrm{Ni}$ and $\mathrm{Zn}$ hydroxides and the adsorption of $\mathrm{Cu}$ and $\mathrm{As}(\mathrm{V})$ on iron hydroxides.
\end{abstract}

\section{Introduction}

AMD is a major environmental concern in the IPB, where volcanogenic massive sulfide ore deposits have been exploited for two millennia. The toxic legacy of this activity is a network of streams and rivers impacted with acid, sulfate-rich and metal polluted waters [1] (Table 1). In the last twenty years, efforts have been made to mitigate AMD acidity and metal(loid) pollution, proving the efficiency of passive treatment systems for AMD remediation $[2,3]$.

Mitigation and regional control of AMD require the construction of concrete-based structures, such as aeration cascades, tanks to hold the materials of the passive treatment systems, and dams to control the level of the rivers [4]. The durability of these concretebased structures depends very much on the processes arising from the interaction between the concrete and the AMD water. Given that these highly polluted waters have very low $\mathrm{pH}$ $(0<\mathrm{pH}<4)$ and high concentrations of sulfate, iron, aluminum and metal(loid)s, the dissolution of the cement phases (e.g. calcium silicate hydrate (C-S-H) and portlandite), precipitation of secondary minerals (e.g. gypsum, goethite, schwertmannite, ettringite, etc.)

* Corresponding author: jordi.cama@idaea.csic.es 
and adsorption of metal(loid)s will be the dominant reactions that determine the fate of the concrete-based structures.

Our goal was to study the effect of these reactions on the mineralogy of the cement and the rock and on the AMD water composition during the cement-rock-AMD interaction to evaluate the consequences for concrete durability. To this end, flow-through column experiments with crushed Portland cement and rock fragments of millimetric size were carried out. As acid metal(loid)-rich solutions circulated through the column at constant flow rate, changes in the aqueous chemistry were monitored. Moreover, the fragments, before and after the experiments, were examined by optical microscopy, XRD and SEM-EDS.

Table 1. Chemical composition of the Tinto Santa Rosa AMD in the IPB.

\begin{tabular}{|c|c|c|c|}
\hline element & $\begin{array}{c}\text { concentration } \\
\text { (ppm) }\end{array}$ & element & $\begin{array}{c}\text { concentration } \\
\text { (ppb) }\end{array}$ \\
\hline $\mathrm{pH}$ & 2.9 & $\mathrm{As}$ & $125-4300$ \\
\hline $\mathrm{Fe}$ & $500-1000$ & $\mathrm{Ni}$ & $450-900$ \\
\hline $\mathrm{S}$ & $2500-4000$ & $\mathrm{~Pb}$ & $1-800$ \\
\hline $\mathrm{Al}$ & $60-130$ & $\mathrm{Cd}$ & $4-170$ \\
\hline $\mathrm{Mn}$ & $30-50$ & $\mathrm{Co}$ & $725-1400$ \\
\hline $\mathrm{Zn}$ & $55-110$ & $\mathrm{~V}$ & $20-100$ \\
\hline $\mathrm{Cu}$ & $15-55$ & $\mathrm{Sb}$ & $3-25$ \\
\hline
\end{tabular}

\section{Materials and methods}

\subsection{Sample characterization}

The rock used was a siliceous limestone with calcite and quartz as primary minerals (68 and $24 \mathrm{wt} \%$, respectively) and with lower quantities of microcline, illite and ankerite $(5,2$, and 1 $\mathrm{wt} \%$, respectively). The Portland cement used in the experiments was composed of C-S-H $(\mathrm{Ca} / \mathrm{Si}=1.67)$, portlandite, ettringite, calcite, hydrotalcite and Si-hydrogarnet $(46.6,24.6$, $13.1,4.1,3.3$ and $8.3 \mathrm{wt} \%$, respectively). The rock and cement samples were crushed and sieved to obtain a 1-2 $\mathrm{mm}$ grain size. The fragments were washed with Millipore Milli-Q water $(18 \mathrm{M} \Omega \mathrm{cm})$ between three and four times to remove the microparticles generated during crushing and dried thereafter at $40{ }^{\circ} \mathrm{C}$ for 24 hours.

\subsection{Experimental setup}

The experimental system allowed a continuous injection of an input solution of known chemical composition through a column filled with rock and Portland cement. One column was assembled for each different input solution ( 7 in total). The temporal variation in the chemical composition ( $\mathrm{pH}, \mathrm{Ca}, \mathrm{Mg}, \mathrm{K}, \mathrm{Si}, \mathrm{Al}, \mathrm{Fe}, \mathrm{S}, \mathrm{Ni}, \mathrm{Zn}$, As and $\mathrm{Cd}$ ) was monitored. The length of the columns was $6 \mathrm{~cm}$ with an inner diameter of $2.6 \mathrm{~cm}$. The columns were filled with two alternating layers of rock (R1 and R2) and cement (C1 and C2) with an approximate porosity of $65 \%$ (Fig. 1). At the bottom and top of the columns, a $5 \mathrm{~mm}$ layer of silica beads was placed to distribute the input solution at the inlet and outlet. All layers were separated with a 0.45 micron inert metallic filter to prevent the mixture of fragments between rock and cement layers. The input solutions were injected at a constant flow rate $\left(\approx 0.07 \mathrm{~mL} \mathrm{~min}^{-1}\right)$ from the bottom upwards using a peristaltic pump. 


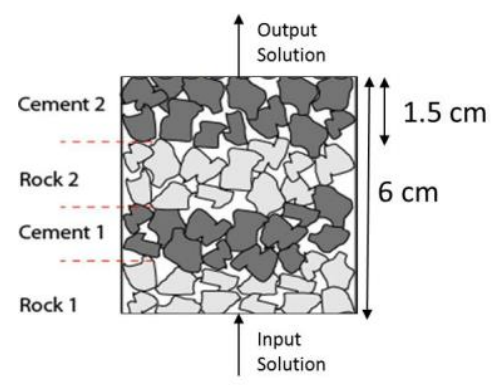

Fig. 1. Scheme of the columns filled with alternating layers of rock (R1 and R2) and Portland cement (C1 and $\mathrm{C} 2)$.

\subsection{Solutions and analysis}

Seven input solutions were prepared at $\mathrm{pH}=2\left(\mathrm{H}_{2} \mathrm{SO}_{4}\right)$. One solution contained only 0.01 $\mathrm{M} \mathrm{H}_{2} \mathrm{SO}_{4}$ and Milli-Q water. The other six solutions contained $\mathrm{H}_{2} \mathrm{SO}_{4}, \mathrm{Al}, \mathrm{Ca}, \mathrm{Mg}$ and $\mathrm{Fe}$ as major ions together with either one divalent cation as a minor component $(\mathrm{Cd}, \mathrm{As}, \mathrm{Cu}$, $\mathrm{Zn}$ and $\mathrm{Ni}$ ) or with all of them (Table 2).

Table 2. Chemical composition of the input solutions: $[\mathrm{Fe}, \mathrm{S}, \mathrm{Al} \mathrm{Mg}, \mathrm{Ca}$ and $\mathrm{Zn}]=[$ table concentration $] \cdot 10^{-3} ;[\mathrm{As}, \mathrm{Cd}, \mathrm{Cu}$ and $\mathrm{Ni}]=[$ table concentration $] \cdot 10^{-4}$.

\begin{tabular}{|c|c|c|c|c|c|c|c|c|c|c|}
\hline & \multicolumn{5}{|c|}{ major element $(\mathrm{M})$} & \multicolumn{5}{|c|}{ minor element (M) } \\
\hline column & $\mathrm{Fe}$ & $\mathrm{S}$ & $\mathrm{Al}$ & $\mathrm{Mg}$ & $\mathrm{Ca}$ & $\mathrm{As}$ & $\mathrm{Cd}$ & $\mathrm{Cu}$ & $\mathrm{Zn}$ & $\mathrm{Ni}$ \\
\hline $\mathrm{SO}_{4}{ }^{2-}$ & 0 & 6.1 & 0 & 0 & 0 & 0 & 0 & 0 & 0 & 0 \\
\hline $\mathrm{Cd}$ & 9.2 & 29 & 3.4 & 5.6 & 4.0 & 0 & 0.03 & 0 & 0 & 0 \\
\hline $\mathrm{As}$ & 9.0 & 30 & 3.3 & 5.5 & 3.9 & 0.08 & 0 & 0 & 0 & 0 \\
\hline $\mathrm{Cu}$ & 9.6 & 32 & 3.5 & 5.9 & 4.2 & 0 & 0 & 3.0 & 0 & 0 \\
\hline $\mathrm{Zn}$ & 8.9 & 31 & 3.0 & 5.2 & 4.2 & 0 & 0 & 0 & 1.1 & 0 \\
\hline $\mathrm{Ni}$ & 9.0 & 30 & 2.9 & 5.3 & 4.2 & 0 & 0 & 0 & 0 & 0.09 \\
\hline all & 9.1 & 32 & 2.9 & 5.3 & 4.0 & 0.1 & 0.04 & 2.7 & 1.1 & 0.1 \\
\hline
\end{tabular}

\section{Results and discussion}

During the experiments (Fig. 2), $\mathrm{pH}$ rapidly increased to $\approx 12$, after which it decreased and remained at $\approx 6$ until the conclusion of the experiments. The output $\mathrm{Ca}$ concentration always exceeded the input one in contrast to that of $\mathrm{S}$, which always showed a deficit. This behavior strongly suggested the precipitation of gypsum. The elevated output $\mathrm{pH}$ at the onset indicated that dissolution of portlandite took place. At this stage, $\mathrm{Ca}$ was abruptly released and $\mathrm{S}$ was at the lowest concentration (Fig. 2), allowing gypsum to precipitate as explained below. A decrease in $\mathrm{Mg}$ concentration and a gradual increase in $\mathrm{Si}$ were also observed.
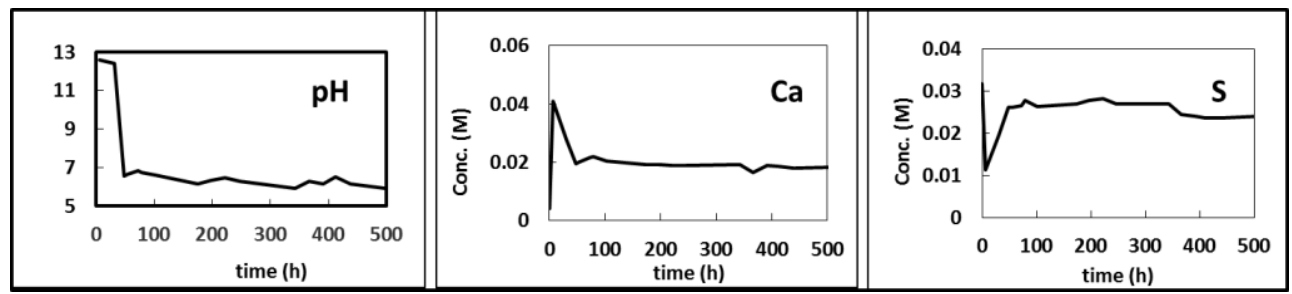

Fig. 2. Variation in $\mathrm{Ca}$ and $\mathrm{S}$ output concentrations and $\mathrm{pH}$ versus time in the column with all-ions input solution $($ Table 2$):[\mathrm{Ca}]_{\mathrm{inp}}=4.0 \cdot 10^{-3} ;[\mathrm{S}]_{\mathrm{inp}}=3.2 \cdot 10^{-2} \mathrm{M} ; \mathrm{pH}_{\text {inp }}=2$. 
Changes in the morphology of primary minerals and the formation of secondary minerals were observed in the four layers (Fig. 3). The size of some calcite fragments decreased with respect to that of quartz, which showed no change. Brownish and whitish precipitates formed among fragments.

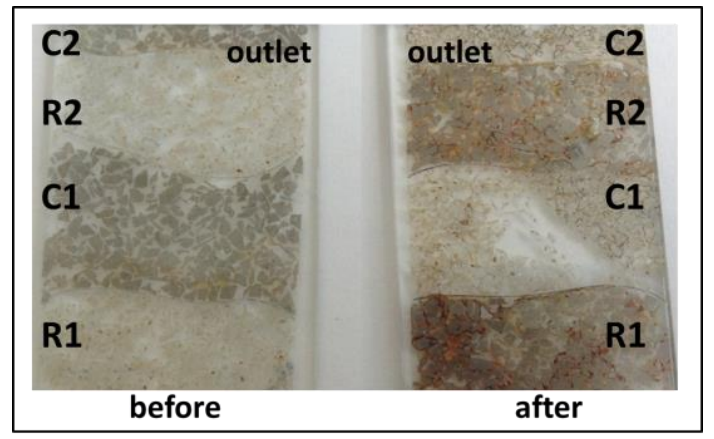

Fig. 3. Photograph of the longitudinal thin sections of a column, which were composed of alternating layers of rock (R1 and $\mathrm{R} 2)$ and Portland cement ( $\mathrm{C} 1$ and $\mathrm{C} 2)$, before and after the experiments.

SEM-EDS inspection of the thin sections showed the existence of aragonite rims on the surfaces of cement fragments. Large gypsum needles grew from the cement-fragment surfaces (Fig. 4). XRD analyses confirmed the formation of these Ca-bearing phases and revealed the formation of schwertmannite and brucite.

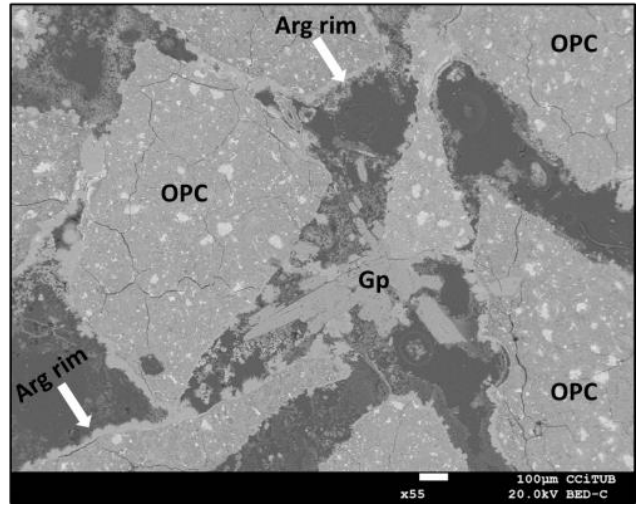

Fig. 4. SEM microphotograph of the first Portland cement (OPC) layer (C1): aragonite (Arg) rims formed on the surface of the cement fragments. Long gypsum $(\mathrm{Gp})$ needles also grew from the surface.

The temporal variation of the concentrations of the divalent cations ( $\mathrm{Fe}(\mathrm{II}), \mathrm{Ni}, \mathrm{Zn}$ and $\mathrm{Cd}$ ) showed total depletion at $\mathrm{pH} \approx 12.5$ that was followed by partial elimination of metals as $\mathrm{pH}$ decreased to $\approx 6.5$ (Fig. 5). This behavior was attributed to the formation of metal hydroxides at high $\mathrm{pH}$. In contrast, arsenate depletion occurred throughout all over the experiments, suggesting As adsorption onto Fe-hydroxides. 


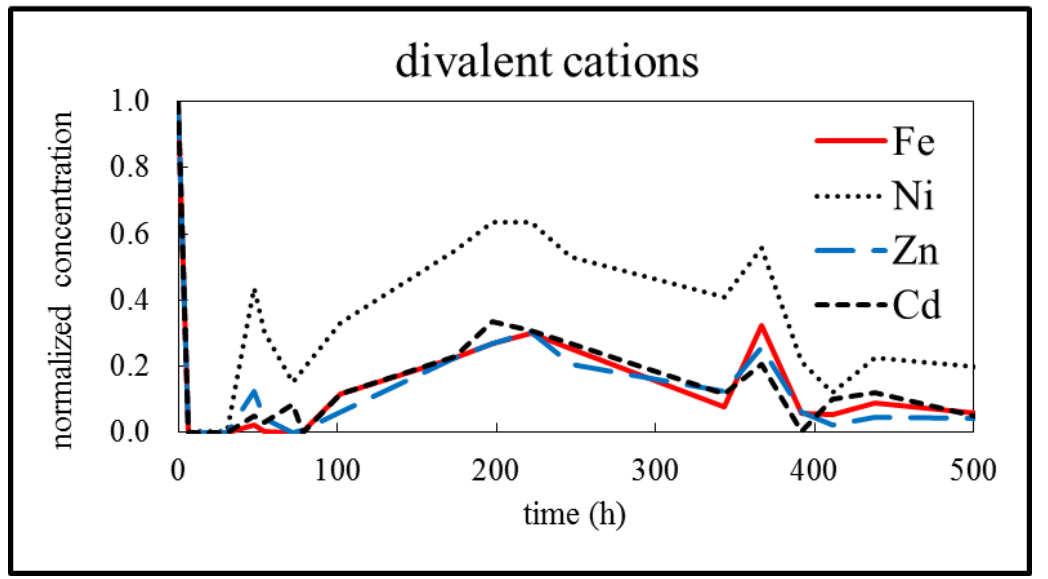

Fig. 5. Variation in normalized concentration of divalent cations versus time.

\section{Summary and conclusions}

Dissolution of calcite (rock) and portlandite (cement) and precipitation of gypsum and aragonite are the main reactions when AMD interacted with the fragments of siliceous limestone and Portland cement. Moreover, the high $\mathrm{pH}$ arising from portlandite dissolution led to the precipitation of brucite and metal-hydroxides. Exhaustion of portlandite caused the $\mathrm{pH}$ decrease with a subsequent limitation on metal depletion. The mineralogical changes observed suggest a probable alteration of Portland-cement-based concrete when in contact with AMD, which causes a deterioration of concrete-based structures.

\section{References}

1. J. Sánchez-España, E. López-Pamo, E. Santofimia, O. Aduvire, J. Reyes, D. Barettino, Appl. Geochem. 20, 1320-1356 (2005)

2. F. Macías, M.A. Caraballo, J.M. Nieto, T.S. Rötting, C. Ayora, J. Env. Manag. 104, 93-100 (2012)

3. M.A. Caraballo, F. Macías, J.M. Nieto, Carlos Ayora, Sci. Tot. Env. 539, 427-435 (2016)

4. M.A. Caraballo, F. Macías, T.S. Rötting, J.M. Nieto, Carlos Ayora, Env. Poll. 159, 3613-3619 (2011) 